\title{
IDE NEGARA KORPORATIS MENURUT SOEPOMO \& BENITO MUSSOLINI
}

\section{Suatu Refleksi Kritis Atas Pengaruh Dan Implikasi Gagasan Korporatisme Dalam Undang-Undang Dasar $1945^{\circ}$}

\author{
E. Fernando M. Manullang ${ }^{1}$
}

\begin{abstract}
Abstrak
This article scrutinizes toward Soepomo 'corporatist state' thoughts influences through Indonesia constitution (UUD RI 1945) that compare to another Benito Mussolini's. The author here finds about the similarity value both Soepomo and Mussolini perspectives regarding character and origin of a state. Those thought is accepted although no any formal claim on UUD RI 1945 is applied corporatist state system but its influence still exist in inside of. The same situation in fascism fashions neither in formal or substantial form can be found in UUD RI 1945. The author keeps curiosity on the similarity thoughts of Soepomo and Mussolini about corporatist state is assumed be influenced by inadequate fascism. The inadequate itself is entitled only by a number of indication and not by plenty facts that direct to there. This assumption has been a Nasution claim on Japanese fascism was persuaded on UUD RI 1945 drafting even in insufficient form.
\end{abstract}

Kata kunci: hukum dasar, Soepomo, Mussolini, negara korporatis, fasisme, UUD RI 1945

Jika kita perhatikan judul diatas, pasti kebanyakan orang akan takjub, sambil bergumam apa urusannya Negara Korporatis dengan Profesor Soepomo? Lalu apa pula hubungannya dengan Benito Mussolini disini?

- Artikel ini adalah ringkasan, dengan penekanan khusus pada subyek Profesor Soepomo, dari naskah buku penulis yang hendak diterbitkan, dengan judul (tentatif): "Korporatisme dan UUD 1945: Interpretasi Hukum terhadap Teks Undang-Undang Dasar 1945 dan Risalah Sidang Badan Penyelidik Oesaha² Kemerdekaan (BPUPK) dan Panitia Persiapan Kemerdekaan Indonesia (PPKI) tentang Pengaruh Nilai Korporatisme dalam Undang-Undang Dasar 1945".

${ }^{1}$ Staf pengajar Fakultas Hukum Universitas Indonesia. Pendidikan terakhirnya di Program Pascasarjana Ilmu Hukum, Fakultas Hukum Universitas Indonesia. 
Hubungan ini bisa diterangkan demikian. Pernah suatu waktu, Profesor Soepomo menyebutkan sebuah istilah Negara Korporatif saat rapat Panitia Hukum Dasar Badan Penyelidik Oesaha Persiapan Kemerdekaan yang diselenggarakan pada $11 \mathrm{Juli} 1945 .^{2}$ Kita tentu akan bertanya-tanya, apa yang dimaksud oleh Profesor Soepomo dengan Negara Korporatif? Lontaran pertanyaan itu, lumrah adanya, karena beberapa literatur kerap mengatakan Profesor Soepomo selalu dihubungkan dengan gagasan atau cita negara, Negara Integralistik atau Negara Kekeluargaan, ${ }^{3}$ daripada Negara Korporatif.

Jika kita sudah sering mendengar atau memerhatikan pendapat Profesor Soepomo perihal cita negara, Negara Integralistik, lalu bagaimana dengan pendapatnya mengenai Negara Korporatif? Elaborasinya, ini yang amat disayangkan, hanya demikian:

Ini ada satu pertanyaan: Apakah yang harus dimasukkan dalam hukum dasar? Beberapa anggota mengatakan bahwa harus dimasukkan misalnya tentang jaminan tentang hak rakyat. Dengan sendirinya ini berpendirian atas teori negara yang saya namakan liberalisme yaitu hak-hak rakyat. Rakyat mempunyai hak kepada pekerjaan, hak kepada hiburan. Umpamanya negeri Austria tahun 1904 sebelum Anschluss dengan Jerman berdasar atas negara yang korporatif. Jerman mengatakan malah tidak

${ }^{2}$ Perihal pernyataan tersebut dapat dilihat dalam Saafroedin Bahar, Ananda B. Kusuma dan Nannie Hudawati, "Risalah Sidang Badan Penyelidik Usaha-Usaha Persiapan Kemerdekaan Indonesia (BPUPKI)-Panitia Persiapan Kemerdekaan Indonesia (PPKI)", (Jakarta: Sekretariat Negara Republik Indonesia, 1995), hal. 220; Dalam risalah yang disusun oleh A. B. Kusuma, bukan istilah negara korporatif yang kita temukan, melainkan negara kooporatif. Lihat hal ini dalam A. B. Kusuma, "Lahirnya Undang-Undang Dasar 1945: Memuat Salinan Dokumen Otentik Badan Oentoek Menyelidiki Oesaha ${ }^{2}$ Persiapan Kemerdekaan", (Depok: Badan Penerbit Fakultas Hukum Universitas Indonesia, 2004), hal. 310.

3 Lihat diantaranya Marsilam Simanjuntak, "Pandangan Negara Integralistik: Sumber, Unsur, dan Riwayatnya dalam Persiapan UUD 1945", (Jakarta: Pustaka Utama Grafiti, 1994); Azhary, "Negara Hukum Indonesia: Analisis Yuridis Normatif Tentang UnsurUnsurnya", (Jakarta: Penerbit Universitas Indonesia, 1995); A. Hamid S. Attamimi, "Peranan Keputusan Presiden Republik Indonesia Dalam Penyelenggaraan Pemerintahan Negara: Suatu Studi Analisis Mengenai Keputusan Presiden Yang Berfungsi Pengaturan Dalam Kurun Waktu Pelita I - Pelita IV,"Disertasi Untuk Memperoleh Gelar Doktor Dalam Ilmu Hukum (Universitas Indonesia, Jakarta, 12 Desember 1990); Lihat dalam Padmo Wajono, "Membudayakan Undang-Undang Dasar 1945", (Jakarta: Ind-Hill-Co, 1991); Lihat juga dalam E. Fernando M. Manullang, "Negara dan Pancasila: Refleksi Kritis Atas Gagasan Hukum Padmo Wahjono", Jurnal Hukum Jentera, Edisi 15-Tahun IV (Januari-Maret 2007), hal. 134-155. 
usah ada hukum dasar, cuma harus ada undang-undang biasa, seperti beberapa undang-undang yang mempunyai aturan yang kokoh. Negeri Inggris pun tidak mempunyai hukum dasar... ${ }^{4}$

Hanya itu penjelasan Profesor Soepomo. Benar-benar sederhana.

Lalu kenapa lantas dihubungkan dengan Benito Mussolini? Ada beberapa alasan yang menjelaskan mengapa kita harus menghubungkannya dengan Mussolini. Pertama, kalau kita bandingkan konteks waktu pada saat pidato Profesor Soepomo disampaikan, tak pelak lagi, aktor politik yang melontarkan ide Negara Korporatis di masa yang sama, adalah Benito Mussolini. ${ }^{5}$ Gagasan tentang negara ini dihadapannya mengandung filosofi dan implikasi politik-ekonomi yang luar biasa. Kedua, kita pun tidak bisa menafikan bahwa Italia dibawah kepemimpinan Mussolini, adalah sebuah negara fasis yang menerapkan model Negara Korporatis dalam sistem ketatanegaraannya. ${ }^{6}$ Walaupun Profesor Soepomo tidak pernah merujukkan pemikirannya kepada negara Italia melainkan negara Jerman, bukan berarti bahwa model Jerman tidak mengimitasi Italia. ${ }^{7}$ Oleh sebab itu, rasanya tepat sekali, jika kita bergerak ke sosok Mussolini untuk mendapatkan penjelasan yang lebih komprehensif mengenai Negara Korporatis.

Dengan demikian, kita telah memahami bahwa ada hubungan kontekstual yang relevan antara Profesor Soepomo dan Mussolini perihal Negara Korporatis. Hubungan kontekstual itu mendorong kita untuk berupaya memahami apa yang dimaksud dengan Negara Korporatis itu sendiri. Namun, disisi lain, karena kita juga sudah menyadari bahwa elaborasi Profesor Soepomo tentang Negara Korporatif tidak memadai, maka

${ }^{4}$ Anschluss berarti dicaplok atau dikuasai secara paksa. Lihat A. B. Kusuma, "Lahirnya Undang-Undang Dasar 1945", hal. 310.

${ }^{5}$ Pidato Benito Mussolini pada pertengahan November 1933 adalah bukti bahwa ia memang salah satu aktor politik yang menyokong gagasan Negara Korporatis. Lihat dalam Benito Mussolini, The Corporate State: With An Appendix Including The Labour Charter, The Text of Laws on Syndical and Corporate Organizations and Explanatory Notes (Firenze: Vallecchi Editore, tanpa tahun); Lihat juga dalam Benito Mussolini, Four Speeches on The Corporate State (tanpa tempat: tanpa penerbit dan tanpa tahun).

${ }^{6}$ Lihat pernyataan ini dalam L. P. Carpenter, "Corporatism in Britain, 1930-45," Journal of Contemporary History, Vol. 11, No. 1. (January 1976), hal. 3-25; Lihat juga Allan Booth, "Corporatism, Capitalism and Depression in Twentieth-Century Britain", The British Journal of Sociology, Vol. 33, No. 2. (June 1982), hal. 200-223.

${ }^{7}$ Lihat dalam J. M. Kelly, "A Short History of Western Legal Theory", (Oxford: Clarendon Press, 2005), hal. 349-350. 
itu kita harus merujuk kepada pemikiran Mussolini tentang Negara Korporatis.

Konsekuensinya, dalam tulisan ini, ada tiga persoalan yang menarik untuk dibahas disini. Pertama, apa yang dimaksud dengan Negara Korporatis dalam pandangan Mussolini? Dengan menjawabnya, kita kira-kira bisa mendapatkan gambaran umum tentang ide Negara Korporatis. Lalu, kedua, apakah ide Mussolini tentang Negara Korporatis memiliki kemiripan karakteristik dengan gagasan Soepomo secara keseluruhan yang disampaikan pada saat perancangan Undang-Undang Dasar 1945? Disini, kita bisa membandingkan kesamaan karakteristik ide Profesor Soepomo tentang staatsidee yang ia idam-idamkan, dalam hal ini Negara Integralistik atau Negara Kekeluargaan. Dan, ketiga, jika memang ada kemiripan secara karakteristik antara pemikiran Mussolini dan Profesor Soepomo, lalu bagaimana implikasinya dalam UUD 1945? Apakah itu berarti UUD 1945 adalah konstitusi Negara Korporatis?

Mari kita diskusikan hal-hal diatas berikut ini.

\section{Ide Negara Korporatis Menurut Benito Mussolini}

Mussolini pernah memberikan sebuah elaborasi yang cukup panjang perihal Negara Korporatis. Pidato itu disampaikan didepan sidang National Council of Corporations pada pertengahan November 1933. Pada intinya, Mussolini mengangankan bahwa dalam Negara Korporatis harus memenuhi unsur-unsur pokok. Unsur-unsur tersebut adalah (i) konsep dan sistem negaranya harus bersifat totaliter, (ii) adanya single party sebagai partai negara, dan (iii) perwakilan fungsional yang mewakili kepentingan asosiasi atau korporasi. ${ }^{8}$

Mengapa sekian unsur itu harus ada dalam Negara Korporatis? Mussolini mengatakan sejumlah alasan dibalik adanya sekian unsur tersebut. Pertama, Mussollini memposisikan gagasannya mengenai Negara Korporatis itu dalam konteks pemikiran Fasisme. Konteks itu dapat dilihat ketika kita memerhatikan gagasan-gagasan ekonominya. Mussollini melihat sistem ekonomi dan politik yang liberal akan runtuh, karena tidak bisa memberikan solusi. Malah ia juga menyatakan kalau sistem ekonomi sosialis yang disampaikan oleh Karl Marx akan menemui kuburannya sendiri, karena terjebak oleh mekanismenya yang birokratis. ${ }^{9}$ Lebih lanjut, Negara

${ }^{8}$ Lihat dalam Benito Mussolini, The Corporate State, passim; Lihat juga dalam Benito Mussolini, Four Speeches on The Corporate State, passim; Bandingkan dengan William Ebenstein, Communism, Fascism, Capitalism, Socialism (New York: Prenticce-Hall, Inc., 1965), hal. 119. 
Korporatis, bagi Mussolini, dianggap sebagai sebuah jalan keluar dari kekacauan dan kegagalan sistem ekonomi yang kapitalis ${ }^{10}$ dan sosialis. Oleh karena itu, dalam pemahaman Fasisme, peranan Negara amat menentukan dalam urusan perekonomian. Kepentingan pribadi yang berwatak kapitalistis dan individualis harus disingkirkan. Kepentingan semacam itu harus diserap dan berhimpun secara korporatis dalam kekuatan asosiasi yang berfungsi sebagai perwakilan fungsional dan Negara itu sendiri, termasuk partai negara.

Alasan kedua. Konsep Mussolini tentang Negara Korporatis yang demikian, itu dikarenakan oleh keinginannya membangun suatu negara yang didasarkan pada prinsip harmoni. Nilai harmoni ini diwujudkan dalam bentuk kerja. Oleh sebab itu, Mussolini menolak secara fundamental gagasan-gagasan yang bersifat liberal dan juga sosialis, karena kedua-duanya itu tidak dibangun diatas nilai harmoni. Nilai harmoni ini menjadi nilai yang penting karena dari sanalah terdapat fondasi utama sistem yang totaliter. Negara dapat dikelola secara harmonis, sehingga, seperti telah dikatakan sebelumnya, seluruh kepentingan dari tiap individu dan kelompok diakomodasi dalam perwakilan yang fungsional sifatnya, atau diatur oleh partai pelopor yang tunggal sifatnya. ${ }^{11}$

Hal-hal tadi adalah alasan fundamental yang menopang keberadaan dari unsur-unsur pokok dari Negara Korporatis. Implikasi dari itu semua, Mussolini lebih mengedepankan konsep dan sistem politik yang totaliter, daripada bertumpu kepada subyek elit yang totaliter, ${ }^{12}$ seperti yang

${ }^{9} \mathrm{Hal}$ ini diakui oleh Vladimir I. Lenin. Lenin pernah mengatakan bahwa prinsip organisasi yang revolusioner adalah birokratisme melawan demokratisme. Ini artinya ada sentralisme melawan otonomisme. Lihat dalam Franz Magnis-Suseno, Dalam Bayangan Lenin: Enam Pemikir Marxisme dari Lenin sampai Tan Malaka (Jakarta: Gramedia Pustaka Utama, 2003), hal. 16.

${ }^{10}$ Pengalaman semacam ini pernah terjadi juga di Perancis. Para kapitalis borjuis dan produsen-produsen kecil, termasuk kelas menengah dan petani, bersimpati dengan gagasan korporatis sebagai akibat dari bangkrutnya industri sutra di Lyon. Lihat dalam Kevin Passmore, "Business, Corporatism and the Crisis of the French Third Republic: The Example of the Silk Industry in Lyon, 1928-1935," The Historical Journal, Vol. 38, No. 4 (December 1995), hal. 959-987.

${ }^{11}$ Uraian diatas disarikan dari Benito Mussolini, The Corporate State, passim; Lihat juga dalam Benito Mussolini, Four Speeches on The Corporate State, passim.

12 Lihat dalam Leonard Schapiro, "Totalitarianism", (London: Macmillan Ltd., 1972), hal. 63-71; Hannah Arendt mengatakan kalau Mussolini memang menolak kepemimpinan yang elit. Menurutnya, setiap pemimpin elit yang totaliter itu dapat diganti sewaktu-waktu. Oleh sebab itu, Mussolini lebih memilih sebuah sistem yang totaliter daripada 
dipraktekkan dimasa Hitler berkuasa. ${ }^{13}$ Pemimpin, bagi Nazi, sudah seperti berhala kepemimpinan yang tidak bisa ditolak. ${ }^{14}$

Namun, tradisi Nazi Jerman yang demikian, tidak terjadi di negara Fasis Italia. Menurut Amos Perlmutter, dalam pandangan kaum Korporatis di Italia, kepemimpinan kaum elit di negara Fasis tidak sekuat dengan apa kita bayangkan. Memang, ada lembaga korporatis tertinggi (grand corporate) yang menjadi pimpinan kolektif di Negara Korporatis. Tapi, pada umumnya, elit tersebut tidak terikat kuat sebagaimana yang terjadi di Negara Komunis. Elit militer dalam Negara Korporatis berkedudukan sebagai cadangan kekuatan politik yang menggerakkan organisasi politik dan negara. Tapi biasanya, elit militer itu tidak terampil secara politik, yang berakibat struktur politik di Negara Korporatis, menjadi mudah goyah. Disaat seperti itulah, ketika terjadi ketidakstabilan politik, para elit militer dalam Negara Korporatis - termasuk Negara Fasis- masuk mengintervensi arena politik. ${ }^{15}$ Ketidakstabilan itu mungkin terjadi, karena pada dasarnya menurut Perlmutter, sifat dari organisasi Negara Korporatis itu yang oligarkis, dan itu membuat peranan partai tidak lebih kuat daripada korporasi itu sendiri. ${ }^{16}$

Oleh sebab itu, sistem totaliter yang mengandalkan kekuatan korporasi menjadi inti dalam tradisi politik Italia semasa Mussolini berkuasa. Itu semua memang disebabkan oleh sebuah filosofi tentang harmoni dan itu bisa terwujud dalam organisasi yang korporatis sifatnya.

kepemimpinan yang totaliter. Lihat dalam Hannah Arendt, "The Origins of Totalitarianism", Fourth Printing (New York: Meridian Books, 1960), hal. 325.

${ }^{13}$ Kesamaan ini tidak bisa dibantah memang, karena Adolf Hitler sesungguhnya mengimitasi model yang dikembangkan oleh Benito Mussolini, sebagaimana dikatakan oleh J. M. Kelly, "A Short History of Western Legal Theory", hal. 349-350.

${ }^{14}$ Lihat Paul Hayes, "Fascism”, (London: George \& Unwin Ltd., 1973), hal. 37.

${ }^{15}$ Amos Perlmutter membedakan konsep Negara Fasis di Italia dan di Jerman, yang berbeda satu sama lainnya. Oleh sebab itu, pengertian tentang Negara Fasis tidak otomatis merujuk kepada Nazi Jerman. Lihat perihal ini dalam Amos Perlmutter, "Modern Authoritarianism: A Comparative Institutional Analysis", (New Haven and London: Yale University Press, 1981), hal. 5-7.

${ }^{16}$ Lihat dalam Amos Perlmutter, "Modern Authoritarianism", hal. 38; Ini pernah terjadi pada 1939 di Italia. Ketika itu, Mussolini memaksa menggantikan peran parlemen dengan Chamber of Corporations. Lihat dalam Robert O. Paxton, "The Anatomy of Fascism", (London: Allen Lane, 2004), hal. 145. 


\section{Ide Negara Integralistik Profesor Soepomo: Ide Negara Korporatis? ${ }^{17}$}

Profesor Soepomo ketika mengajukan gagasannya tentang Negara Integralistik, menyatakan bahwa dia tidak menyetujui bentuk negara yang dibangun diatas paham perserorangan maupun didasarkan pada kepentingan kelas (golongan). Menurutnya, bentuk yang paling cocok dengan karakter bangsa Indonesia adalah sebuah bentuk negara yang mengedepankan semangat kekeluargaan. Dalam negara semacam itu tidak ada pertentangan, atau dalam kata lain terdapat harmoni kepentingan, karena negara dikelola layaknya keluarga yang harmonis. Oleh karena itulah, Profesor Soepomo pun secara tegas menyatakan bahwa urusan hak-hak dasar tidak perlu diatur dalam konstitusi. Menurutnya, pengaturan itu akan berdampak adanya paham yang bersifat perseorangan dalam konstitusi. Dan hal itu tidak sesuai dengan karakter bangsa Indonesia.

Profesor Soepomo pun kemudian menyatakan bahwa perwakilan golongan adalah salah unsur penting yang bisa menjamin terjaganya paham kekeluargaan itu dalam Majelis Permusyawaratan Rakyat (MPR). Perwakilan fungsional itu diambil dari badan-badan perekonomian dan serikat sekerja. ${ }^{18}$ Oleh sebab itu, pengisian jabatannya bukan melalui mekanisme pemilihan. ${ }^{19}$ Lalu, Profesor Soepomo menyatakan kalau dalam urusan perekonomian juga demikian. Menurutnya, perlu diterapkan sistem "sosialisme negara" ${ }^{20}$ yang sesuai dengan paham integralistik. Oleh sebab itu, sifat dari kegiatan ekonomi harus disusun berdasar paham kekeluargaan, ada sistem tolongmenolong dan itu bisa dijalankan dengan menggunakan sistem koperasi sebagai dasar ekonomi negara. ${ }^{21}$

${ }^{17}$ Uraian mengenai pidato atau pendapat Profesor Soepomo diringkas dari A. B. Kusuma, "Lahirnya Undang-Undang Dasar 1945", passim.

${ }^{18}$ Berbeda dengan Italia, pengaturan tentang badan-badan apa saja yang dapat digolongkan sebagai utusan/perwakilan yang fungsional, diatur dengan rinci. Lihat dalam Benito Mussolini, "The Corporate State", passim.

${ }^{19}$ Usulan pengisian jabatan melalui mekanisme penunjukkan ini disampaikan oleh anggota Hatta, karena jika melalui mekanisme pemilihan, maka itu berlawanan dengan prinsip kekeluargaan itu sendiri. Lihat hal ini dalam Lihat juga dalam Ananda B. Kusuma, "Lahirnya Undang-Undang Dasar 1945", passim.

20 Tanda petik pada istilah tersebut, dikutip sebagaimana aslinya dalam naskah "Lahirnya Undang-Undang Dasar 1945".

${ }^{21}$ Lihat A. B. Kusuma, "Lahirnya Undang-Undang Dasar 1945", hal. 132. 
Gagasan-gagasan Profesor Soepomo yang demikian, mengundang sebuah kecurigaan yang mendalam bahwa ia sebenarnya terpengaruh juga oleh gagasan Negara Korporatis. Apalagi kalau kita melacak tokoh rujukan pemikirannya, yakni Adam Müller. ${ }^{22}$ Menurut Herbert Wallace Schneider, Adam Müller adalah salah seorang sarjana yang berperan memberikan dasardasar pemikiran tentang Korporatisme. ${ }^{23}$ Memang, ketika para anggota Panitia Persiapan memutuskan untuk membentuk sebuah partai negara, Profesor Soepomo tidak melontarkan suatu pernyataan apapun. ${ }^{24}$ Walaupun demikian, sebagian besar ide Profesor Soepomo tentang nilai harmoni yang ada dalam wadah yang kekeluargaan, penolakannya terhadap gagasan ideologis yang berwatak liberal maupun sosialis, penolakannya juga terhadap keberadaan hak-hak dasar, lalu persetujuannya tentang utusan golongan sebagai perwakilan fungsional, termasuk gagasan ekonominya yang berwatak kekeluargaan, dapat dikategorikan kalau dirinya memiliki kesamaan ide dengan gagasan Mussolini tentang Negara Korporatis.

Gagasan Soepomo dan Mussolini mengandung kemiripan karena pada intinya mereka berdua berangkat dari sebuah filosofi yang serupa: bahwa keduanya menghendaki nilai harmoni yang totaliter. Filosofi ini memberikan implikasi yang hampir serupa pula dalam hal-hal tertentu.

Walaupun demikian, kita harus ingat secara hati-hati, apabila mereka berdua memiliki kesamaan tertentu dalam gagasan negara, bukan berarti kita juga bisa menyatakan secara tegas-tegas kalau keduanya memang betul-betul identik. Keduanya memiliki latar belakang yang berbeda, apalagi kalau kita perhatikan situasi politik-ekonomi di Indonesia dan Italia. Saat itu, Indonesia adalah negara jajahan, sementara Italia bukan, walau keduanya sama-sama antipati terhadap ide-ide liberal maupun yang berpaham konflik antarkelas. Titik berangkat yang berbeda itu bisa dilihat ketika rejim Mussolini berhasil menstrukturisasi asosiasi-asosiasi buruh dan kapitalis. ${ }^{25}$ Sementara Indonesa

22 Lihat perihal pernyataan Profesor Soepomo mengenai Adam Müller dalam Marsillam Simanjuntak, Pandangan Negara Integralistik, passim; Lihat juga dalam Muhammad Yamin, "Naskah Persiapan UUD 1945, Djilid Pertama", (Jakarta: Yayasan Prapantja, 1959), passim; Lihat juga Saafroedin Bahar, Ananda B. Kusuma dan Nannie Hudawati, "Risalah Sidang BPUPKI-PPKI", passim; Lihat juga dalam A. B. Kusuma, "Lahirnya Undang-Undang Dasar 1945", passim.

23 Lihat dalam Herbert Wallace Schneider, "Corporate State", Encyclopaedia Britannica: A New Survey of Universal Knowledge, Vol. 6 (Chicago, London \& Toronto: Encyclopaedia Britannica, Ltd., 1955), hal. 472-474.

${ }^{24}$ Usulan ini datang dari anggota Iwa Kusumasumantri. Lihat dalam A. B. Kusuma, "Lahirnya Undang-Undang Dasar 1945", hal. 515 et seqq. 
kala itu belum pada tahap dan kebutuhan untuk melakukan hal seperti yang Mussolini lakukan. Sehingga gagasan Profesor Soepomo tentang Negara Korporatis masih berada dalam tataran konseptual daripada sebagai agenda politik yang praktis seperti yang telah dilakukan oleh Mussolini.

\section{UUD 1945: Konstitusi Negara Korporatis yang Berwatak Fasistis?}

Oleh sebab itu, kesamaan ide itu bukan berarti dapat ditafsirkan bahwa UUD 1945 secara formal mengadopsi gagasan Negara Korporatis. Tambah lagi, pada faktanya tidak ada satupun teks dalam UUD 1945 yang memberikan penegasan bahwa bentuk negara yang diakui secara formal dalam UUD 1945 adalah Negara Korporatis.

Namun persoalannya, ada juga fakta yang menyatakan bahwa nilainilai yang dikandung oleh gagasan Negara Korporatis, terkandung juga dalam UUD 1945. Itu bisa dilihat ketika para anggota pada umumnya sepakat diterimanya ide kekeluargaan dalam urusan perekonomian, termasuk kaitannya dengan keberadaan utusan golongan di Majelis Permusyawaratan Rakyat (MPR) ${ }^{26}$ Padahal, secara metodis, nilai-nilai itu menjadi fondasi penting dari adanya asas hukum dalam suatu kaedah hukum. Atau dengan perkataan lain, keberadaan norma hukum sesungguhnya ditopang oleh suatu fondasi yang disebut sebagai asas hukum, dimana didalamnya terdapat nilainilai karena pada intinya, asas hukum ini memang berbentuk berupa suatu pemikiran yang abstrak mengenai hukum. ${ }^{27}$

Persoalan tadi amat dilematis untuk dipastikan, karena ini adalah persoalan yang interpretatif ${ }^{28}$ dan hermeneutis, karena masing-masing pihak

${ }^{25}$ Rejim Mussolini berhasil menggalang seluruh kekuatan itu ke dalam suatu struktur politik yang monistis dan fungsional. Tiap serikat buruh atau kekuatan modal dihimpun dalam suatu organisasi yang tunggal dari tingkat nasional hingga ke tingkat terendah sesuai dengan fungsi-fungsinya. Jumlah keseluruhannya adalah 21 korporasi (asosiasi). Lihat hal ini dalam Benito Mussolini, "The Corporate State", hal. 65 et segq.

${ }^{26}$ Diantara yang menyatakan secara terbuka setuju dengan ide ini diluar Profesor Soepomo adalah anggota P. F. Dahler, Soesanto Tirtoprodjo, Liem Koen Hian dan Hatta. Lihat dalam A. B. Kusuma, Lahirnya Undang-Undang Dasar 1945, passim.

27 Lihat dalam Soedikno Mertokusumo, Mengenal Hukum: Suatu Pengantar, Cetakan Kedua, Edisi Keempat (Yogyakarta: Penerbit Liberty, 1999), hal. 33-34.

28 Purnadi Purbacaraka dan Soerjono Soekanto menyatakan bahwa untuk menjelaskan makna dari undang-undang digunakan suatu alat ilmiah yakni interpretasi. Lihat dalam Purnadi Purbacaraka dan Soerjono Soekanto, "Perundang-Undangan dan Yurisprudensi”, Cetakan Kedua (Bandung: Penerbit Alumni, 1986), hal. 21-22; Perihal ruparupa interpretasi, lihat dalam Sudikno Mertokusumo dan A. Pitlo, "Bab-Bab Tentang Penemuan Hukum", Cetakan Pertama (Bandung: Citra Aditya Bakti, 1993), hal. 11-21; Lihat 
dalam memahami suatu teks hukum, tidak dibatasi pada upaya penafsiran terhadap teks itu sendiri, namun juga menjangkau aspek-aspek lainnya yang tidak nampak dalam teks tersebut, seperti prasangka atau motif politis dan lainnya. ${ }^{29}$ Oleh karenanya, tiap-tiap pihak dapat menafsirkannya demikian, atau sebaliknya, malah menolak sama sekali tuduhan semacam itu. Penolakan itu bersumber dari sebuah kenyataan diterimanya gagasan demokratis dalam UUD 1945, berupa diterimanya mekanisme pemilihan kepala negara dan hak-hak dasar warga. ${ }^{30}$

Jika, katakanlah, nilai dari gagasan Negara Korporatis atau pengaruhnya dianggap eksis dalam UUD 1945, apakah bisa disimpulkan bahwa UUD 1945 bernuansa fasis? Pertanyaan itu relevan untuk diajukan karena Roger Eatwell menyatakan bahwa gagasan korporatis itu sebenarnya diakomodasi dalam paham Fasisme. ${ }^{31}$ Menurut William Ebenstein, adanya

juga Yudha Bhakti Ardhiwisastra, "Penafsiran dan Konstruksi Hukum", Cetakan Pertama (Bandung: Penerbit Alumni, 2000), hal. 9-12.

${ }^{29}$ Lihat perihal ini dalam Bernard Arief Sidharta, "Refleksi Tentang Struktur Ilmu Hukum: Sebuah Penelitian Tentang Fundasi Kefilsafatan dan Sifat Keilmuan Ilmu Hukum Sebagai Landasan Pengembangan Ilmu Hukum Nasional Indonesia", Cetakan Kedua (Bandung: Penerbit Mandar Maju, 2000), hal. 160-163; Lihat juga dalam Bambang Triatmoko, "Hermeneutika Fenomenologi Paul Ricouer", dalam "Hakikat Pengetahuan dan Cara Kerja Ilmu-Ilmu", ed. R. Bambang Rudianto, et al., Cetakan Pertama (Jakarta: Gramedia Pustaka Utama, 1993), hal. 61-76; Gerald L. Bruns, "Law and Language: A Hermeneutics of Legal Text", dalam "Legal Hermeneutics: History, Theory, and Practice", ed. Gregory Leyh (Berkeley, Los Angeles and Oxford: University of California Press, 1992), hal. 23-40; E. Sumaryono, "Hermeneutik: Sebuah Metode Filsafat", Cetakan Kesepuluh (Yogyakarta: Penerbit Kanisius, 1999), hal. 23 et seqq; Hans-Georg Gadamer, "Truth and Method", (London: Sheed \& Ward, 1975), hal. 289 et seqq.; Johanis Ohoitimur, "Metafisika Sebagai Hermeneutika: Cara Baru Memahami Filsafat Spekulatif Thomas Aquinas dan Alfred North Whitehead", Cetakan Pertama (Jakarta: Penerbit Obor, 2006), hal. 173; Jean Grondin, "Introduction to Philosophical Hermeneutics", (New Haven and London: Yale University Press, 1994), hal. 109; Brad Sherman, "Hermenutics in Law", The Modern Law Review, Vol. 51, No. 3. (May, 1988), hal. 386-402; Steve Bouma-Prediger, "Rorty's Pragmatism and Gadamer's Hermeneutics," Journal of the American Academy of Religion, Vol. 57, No. 2 (Summer, 1989), hal. 313-324; Joel C. Weinsheimer, Gadamer's Hermeneutics: A Reading of Truth and Method (New York and London: Yale University Press, 1985), hal. 1 et seqq.; Gregory Leyh, "Toward a Constitutional Hermeneutics," American Journal of Political Science, Vol. 32, No. 2 (May, 1988), hal. 369-387; Jazim Hamidi, Hermeneutika Hukum: Teori Penemuan Hukum Baru dengan Interpretasi Teks, Cetakan Pertama (Yogyakarta: UII Press, 2005), hal. 1 et seqq.; C. Verhak, "Aliran Hermeneutik: Bergumul dengan Penafsiran," dalam Para Filsuf Penentu Gerak Zaman, ed. F. X. Mudji Sutrisno dan F. Budi Hardiman, et al., Cetakan Pertama (Yogyakarta: Penerbit Kanisius), hal. 73-81.

${ }^{30}$ Lihat Marsillam Simanjuntak, P"andangan Negara Integralistik", hal. 231 et seqq. 
hubungan antara ide Negara Korporatis dan Fasisme, itu dapat dilihat dalam urusan perekonomian. Seluruh urusan ekonomi dikontrol oleh Negara, sehingga kekuatan buruh dan modal terserap oleh Negara. Lalu oleh Negara, masing-masing kekuatan diberi kekuasaan yang monopolisitik, baik dalam bidang perdagangan maupun pekerjaannya. Untuk mengatasi agar seluruh kontrol tersebut dapat terlaksana dengan baik, Negara, oleh sebab itu, dibutuhkan sebuah partai negara yang tunggal sifatnya. Tugas partai ini adalah sebagai arbiter tertinggi bagi setiap konflik yang lahir antara kekuatan modal dan buruh. ${ }^{32}$

Jika demikian, pendapat Ebenstein itu tidak mengafirmasi sama sekali bahwa UUD 1945 mengandung watak fasistis. UUD 1945 tidak mengatur sistem perekonomian yang monopolistik bagi kekuatan kelompok fungsional, khususnya kelompok buruh. Memang, para perancang UUD 1945 memutuskan untuk membentuk suatu partai negara, namun ide itu tidak tuntas formatnya. Para perancang konstitusi tidak merinci lebih dalam lagi apakah partai negara ini akan menjadi arbiter dari setiap konflik yang lahir diantara buruh dan pemilik modal.

Jadi, kalau kita perhatikan paparan diatas, yang bisa kita katakan hanyalah, bahwa ada kesamaan nilai antara Profesor Soepomo dengan Mussolini dalam memandang sifat dan hakekat sebuah negara. Oleh sebab itu, walaupun tidak ada klaim secara formal bahwa UUD 1945 itu menganut sistem Negara Korporatis, pengaruh itu ada masih tetap ada disana. Begitu juga dalam hal paham Fasisme. Secara formal, apalagi secara substansial, memang tidak ada ideologi Fasisme dalam UUD 1945. Namun, jika kita menerima bahwa ada kesamaan gagasan antara Profesor Soepomo dan Mussolini dalam nilai-nilai dari sistem Negara Korporatis, hal ini tidak menutup kemungkinan bahwa kita bisa mengasumsikan adanya pengaruh secara terbatas nilai-nilai dari paham Fasisme. Mengapa dikatakan secara terbatas? Karena ada sekian indikasi, bukan fakta, yang mengarah kesana. Oleh sebab itu, wajar, jika Adnan Buyung Nasution kemudian mengatakan bahwa ada pengaruh fasisme Jepang ketika UUD 1945 dirancang, ${ }^{33}$ karena pada dasarnya, pengaruh itu memang ada secara terbatas, seperti kita telah refleksikan diatas.

${ }^{31}$ Lihat Roger Eatwell, "Fascism", dalam "Contemporary Political Idelogies", ed. Roger Eatwell and Anthony Wright, (Boulder, San Francisco: Westview Press, 1993), hal. 169-191.

${ }^{32}$ Lihat dalam William Ebenstein, Today's ISMS, hal. 117.

${ }^{33}$ Lihat Adnan Buyung Nasution, "The Aspiration for Constitutional Government in Indonesia: A Socio-Legal Study of the Indonesian Konstituante 1956-1959", (Jakarta: Pustaka Sinar Harapan, 1992), hal. 6-12. 


\section{Daftar Pustaka}

Ardhiwisastra, Yudha Bhakti. Penafsiran dan Konstruksi Hukum, Cetakan Pertama, Bandung: Penerbit Alumni, 2000.

Arendt, Hannah. The Origins of Totalitarianism, Fourth Printing, New York: Meridian Books, 1960.

Attamimi, A. Hamid S. "Peranan Keputusan Presiden Republik Indonesia Dalam Penyelenggaraan Pemerintahan Negara: Suatu Studi Analisis Mengenai Keputusan Presiden Yang Berfungsi Pengaturan Dalam Kurun Waktu Pelita I - Pelita IV", Disertasi Untuk Memperoleh Gelar Doktor Dalam Ilmu Hukum, (Universitas Indonesia, Jakarta, 12 Desember 1990).

Azhary. Negara Hukum Indonesia: Analisis Yuridis Normatif Tentang Unsur-Unsurnya, Jakarta: Penerbit Universitas Indonesia, 1995.

Bahar, Saafroedin, Kusuma, Ananda B. dan Hudawati, Nannie. Risalah Sidang Badan Penyelidik Usaha-Usaha Persiapan Kemerdekaan Indonesia (BPUPKI)-Panitia Persiapan Kemerdekaan Indonesia (PPKI), Jakarta: Sekretariat Negara Republik Indonesia, 1995.

Booth, Allan. Corporatism, Capitalism and Depression in Twentieth-Century Britain, "The British Journal of Sociology", Vol. 33, No. 2. June 1982: 200-223.

Bouma-Prediger, Steve. Rorty's Pragmatism and Gadamer's Hermeneutics, "Journal of the American Academy of Religion", Vol. 57, No. 2 Summer, 1989: 313-324;

Bruns, Gerald L. Law and Language: A Hermeneutics of Legal Text, dalam Legal Hermeneutics: History, Theory, and Practice, ed. Gregory Leyh. Berkeley, Los Angeles and Oxford: University of California Press, 1992.

Carpenter, L. P. Corporatism in Britain, 1930-45, "Journal of Contemporary History", Vol. 11, No. 1. January 1976: 3-25.

Eatwell, Roger. Fascism, dalam Contemporary Political Idelogies, ed. Roger Eatwell and Anthony Wright. Boulder, San Francisco: Westview Press, 1993: 169-191.

Ebenstein, William. Communism, Fascism, Capitalism, Socialism, New York: Prentice-Hall, Inc., 1965.

Gadamer, Hans-Georg. Truth and Method, London: Sheed \& Ward, 1975. 
Grondin, Jean Introduction to Philosophical,Hermeneutics, New Haven and London: Yale University Press, 1994.

Hamidi, Jazim. Hermeneutika Hukum: Teori Penemuan Hukum Baru dengan Interpretasi Teks. Cetakan Pertama. Yogyakarta: UII Press, 2005.

Hayes, Paul. Fascism, London: George \& Unwin Ltd., 1973.

Kelly, J. M. A Short History of Western Legal Theory, Oxford: Clarendon Press, 2005.

Kusuma, A. B. Lahirnya Undang-Undang Dasar 1945: Memuat Salinan Dokumen Otentik Badan Oentoek Menjelidiki Oesaha ${ }^{2}$ Persiapan Kemerdekaan, Depok: Badan Penerbit Fakultas Hukum Universitas Indonesia, 2004.

Leyh, Gregory. Toward a Constitutional Hermeneutics, "American Journal of Political Science", Vol. 32, No. 2. May, 1988: 369-387.

Magnis-Suseno, Franz. Dalam Bayangan Lenin: Enam Pemikir Marxisme dari Lenin sampai Tan Malaka, Jakarta: Gramedia Pustaka Utama, 2003.

Manullang, E. Fernando M. Negara dan Pancasila: Refleksi Kritis Atas Gagasan Hukum Padmo Wahjono, "Jurnal Hukum Jentera", Edisi 15Tahun IV, Januari-Maret 2007: 134-155.

Mertokusumo, Sudikno dan Pitlo, A. Bab-Bab Tentang Penemuan Hukum, Cetakan Pertama. Bandung: Citra Aditya Bakti, 1993.

Mertokusumo, Soedikno. Mengenal Hukum: Suatu Pengantar, Cetakan Kedua, Edisi Keempat. Yogyakarta: Penerbit Liberty, 1999.

Mussolini, Benito. The Corporate State: With An Appendix Including The Labour Charter, The Text of Laws on Syndical and Corporate Organizations and Explanatory Notes, Firenze: Vallecchi Editore, tanpa tahun.

- Four Speeches on The Corporate State, tanpa tempat: tanpa penerbit dan tanpa tahun.

Nasution, Adnan Buyung. The Aspiration for Constitutional Government in Indonesia: A Socio-Legal Study of the Indonesian Konstituante 19561959, Jakarta: Pustaka Sinar Harapan, 1992.

Ohoitimur, Johanis. Metafisika Sebagai Hermeneutika: Cara Baru Memahami Filsafat Spekulatif Thomas Aquinas dan Alfred North Whitehead, Cetakan Pertama, Jakarta: Penerbit Obor, 2006. 
Passmore, Kevin. Business, Corporatism and the Crisis of the French Third Republic: The Example of the Silk Industry in Lyon, 1928-1935, The Historical Journal, Vol. 38, No. 4. December 1995: 959-987.

Paxton, Robert O. The Anatomy of Fascism, London: Allen Lane, 2004.

Perlmutter, Amos. Modern Authoritarianism: A Comparative Institutional Analysis, New Haven and London: Yale University Press, 1981.

Purbacaraka, Purnadi dan Soekanto, Soerjono. Perundang-Undangan dan Yurisprudensi, Cetakan Kedua. Bandung: Penerbit Alumni, 1986.

Schapiro, Leonard. Totalitarianism, London: Macmillan Ltd., 1972.

Schneider, Herbert Wallace. Corporate State, Encyclopaedia Britannica: A New Survey of Universal Knowledge, Vol. 6. Chicago, London \& Toronto: Encyclopaedia Britannica, Ltd., 1955: 472-474.

Sherman, Brad. Hermenutics in Law, "The Modern Law Review", Vol. 51, No. 3. May, 1988: 386-402.

Sidharta, Bernard Arief. Refleksi Tentang Struktur Ilmu Hukum: Sebuah Penelitian Tentang Fundasi Kefilsafatan dan Sifat Keilmuan Ilmu Hukum Sebagai Landasan Pengembangan Ilmu Hukum Nasional Indonesia, Cetakan Kedua, Bandung: Penerbit Mandar Maju, 2000.

Simanjuntak, Marsilam. Pandangan Negara Integralistik: Sumber, Unsur, dan Riwayatnya dalam Persiapan UUD 1945, Jakarta: Pustaka Utama Grafiti, 1994.

Sumaryono, E. Hermeneutik: Sebuah Metode Filsafat, Cetakan Kesepuluh. Yogyakarta: Penerbit Kanisius, 1999.

Triatmoko, Bambang. "Hermeneutika Fenomenologi Paul Ricouer", dalam Hakikat Pengetahuan dan Cara Kerja Ilmu-Ilmu, ed. R. Bambang Rudianto, et al. Cetakan Pertama, Jakarta: Gramedia Pustaka Utama, 1993.

Verhak, C. Aliran Hermeneutik: Bergumul dengan Penafsiran," dalam Para Filsuf Penentu Gerak Zaman, ed. F. X. Mudji Sutrisno dan F. Budi Hardiman, et al. Cetakan Pertama, Yogyakarta: Penerbit Kanisius.

Wajono, Padmo. Membudayakan Undang-Undang Dasar 1945, Jakarta: IndHill-Co, 1991.

Weinsheimer, Joel C. Gadamer's Hermeneutics: A Reading of Truth and Method, New York and London: Yale University Press, 1985. 
Yamin, Muhammad. Naskah Persiapan UUD 1945, Djilid Pertama, Jakarta: Yayasan Prapantja, 1959. 